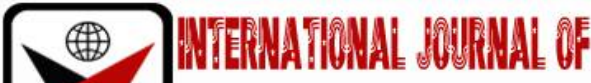

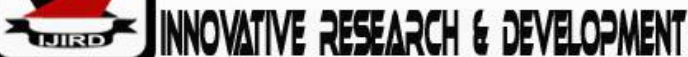

ISSN 2278-0211 (Online)

\section{Management Approach as an Influence of Credit Accessibility on Growth Small and Medium Enterprises in Kenya: A Case of Kisumu County}

Sati William
Student, School of Business and Economics,
Jaramogi Oginga Odinga University of Science and Technology, Kenya
Dr. Michael Nyagol
Dean, School of Business and Economics,
Jaramogi Oginga Odinga University of Science and Technology, Kenya
Dr. Benson Charles Odongo
Director, School of Education,
Jaramogi Oginga Odinga University of Science and Technology, Kenya

\begin{abstract}
:
Internationally, management approach to both Microfinance Institutions (MFIs) and Small and Medium Enterprises (SMEs) play major role in economic growth through credit accessibility. Credit accessibility and socioeconomic growth has a strong correlation (Christen, Rosenberg and Jayadeva, 2004). Studies indicate that in both advanced economies and developing countries, SMEs contribute on average $60 \%$, about three-quarters of total formal employment in the informal sector (Ayyagari et al, 2007). SMEs are impetus to the economic growth and contributor towards millennium development goals and Kenyan vision 2030. Management approach of the sector is an input to the national objective of creating employment opportunities, training operators of small enterprises, generating income and providing a source of livelihood for the majority of low-income households in the country (Republic of Kenya, 1989, 1992, 1994), accounting for 12 - 14\% of GDP. With about 70\% of such enterprises located in rural areas, the sector has a high potential for contributing to rural development. Credit accessibility will result in employment creation, human sociodevelopment and growth to Small and Medium Enterprises (Helms 2006). Everyday around the world, an average of 20,000 SMEs socioeconomic lives grows and are saved from extreme poverty because of the credit accessibility they get from MFIs. Most SMEs with credit accessibility have strong growth and able to mitigate development challenges; (Sachs 2005). In Kenya, credit accessibility has to a larger extent helped in the growth of the socioeconomic rural community (Betty, 2006), currently through innovative approaches, many commercial banks and other microfinance institutions targets the SMEs vide group lending's, progressive lending, regular repayment schedules, and collateral substitutes with a view to growing SMEs ventures.
\end{abstract}

Keywords: Management Approach

\section{Study problem}

The problem of the study focuses on the following main question: With the massive presence of over sixty six MFIs, over twenty commercial banks and numerous Sacco's in Kisumu county, many SMEs were still not registered members of these MFIs service providers, the few registered SMEs were gradually declining in seeking credit, e.g.; only $12 \%$ of SMEs operating in Kisumu East sub-county had accessed credit in the year 2015, the poor performance of SMEs growth as indicated by the county's slow economic index of 2.8\% (CGK 2015) and Kisumu's high poverty level (47.8\%) Does Management approach have an influence of credit accessibility on growth of Small and Medium Enterprises in Kisumu County? 


\section{Document Analysis: Poverty Level in Kisumu with Surrounding Counties}

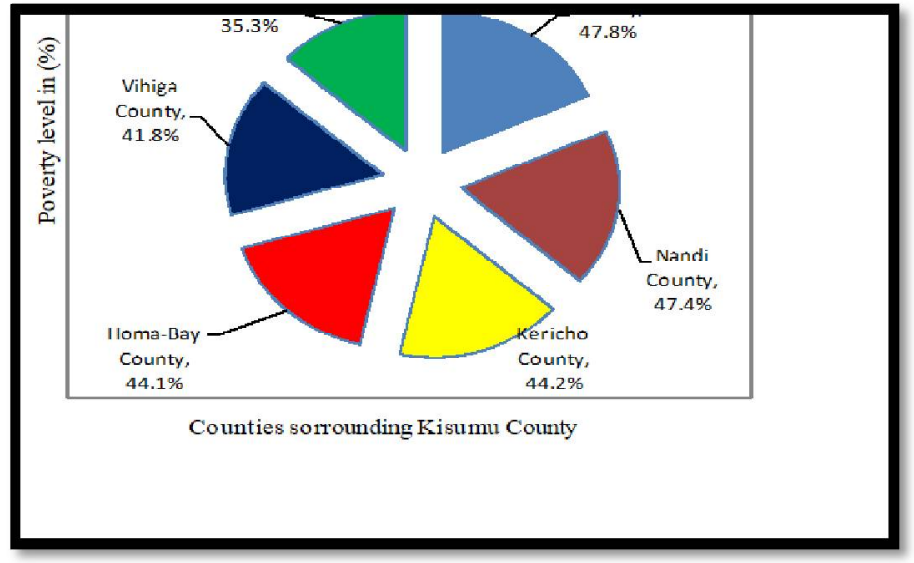

Figure 1

Source; Kenya Integrated Household Budget Survey (KIHBS-2011)

\subsection{Objectives of the Study}

To establish how Management approach, influence the growth of Small and Medium Enterprises in Kisumu County.

\subsection{Significance of the Study}

The significance of this study may benefit a number of stakeholders; Ministry of Finance as policy implementing agency in making relevant assessment policies that safeguard influence of credit accessibility on growth of small and medium enterprises in Kisumu County. The information may also assist the Government in supervising the agency concerned on implementation of Microfinance Act 2006 CAP 493D to its effective results. It may provide potential creditors with full information regarding MFIs and their services, future research students pursuing similar studies on credit accessibility. It may further create awareness among SMEs on the ability to manage credits and also help the Ministry of Cooperative who is responsible for the registration of MFIs in Kenya, by clearly creating awareness to the public for ease of credit accessibility and growth of SMEs.

The findings shall therefore assist the current and future managers of SMEs in understanding the policy required for good governance and fair competition.

\subsection{Study Hypotheses}

The major study hypothesis for this research was;

- $\mathrm{H}_{\mathrm{o}} \quad$ There is no significant relationship between the influence of Management approach and growth of Small and Medium Enterprises in Kisumu County.

- $\mathrm{H}_{1} \quad$ There is significant relationship between the influence of Management approach and growth of Small and Medium Enterprises in Kisumu County.

\subsection{Previous Studies}

In Uzbekistan Central Asia, a study was carried by Nargiza et al (2015) on importance of good management for the growth of SMEs; the study aimed at finding relationship between good management of MSEs and access to business and domestic credits the study revealed that, SMEs from busy towns of Uzbekistan that is; Tashkent region and Fergana region relied on non-bank MFIs on credit due to induction training offered before loans were issued and most of SMEs closer to MFIs benefitted from accessing credits. The study recommended that induction training be part and parcel of field marketing to reach-out to more SMEs seeking credits and improve their credit management while reducing defaulters. Findings from the study revealed that, lack of marketing contributed to slow accessibility of credits, this will foster faster growth and development.

In Pakistan a study carried by Nida (2010) on Impact of microfinance management approach to SMEs, the study aimed at income and employment generation in the poverty-stricken region with few SMEs. The study revealed improvement on income and increased employment to mostly youths in the informal sector due to literacy level which improved out of the workshop that was offered by MFIs to intended credit seekers. The management of loans by SMEs as per the terms offered by MFIs was a gradual training that improved socioeconomic status of SMEs operators. The findings revealed SMEs that went through with training by MFIs on how to manage credits were successful and grew faster economically to attain stability against the non-trained SMEs.

In Bangladesh, Khan and Rahaman (2007) carried a research on Impact of Microfinance involvement to Poor People living in Chittagong District of Bangladesh. The study aimed at; living standards, economic empowerment and poverty alleviation. The study revealed that several microfinance institutions (MFIs) came up and succeeded in reaching out to the poorest of the poor through teaching the locals on the benefits of creating small and medium enterprises (SMEs) in order to access credits in collaterals and groups loaning systems. Since then, results revealed a positive response in 
terms of growth of SMEs. The study recommended that collaterals and group loaning's were best practiced when management approach by MFIs to SMEs was done to poor people whose living standard was economically one empowered.

In Ghana, a study was carried by Yeboah (2010) on MFIs management and development in rural Ghana, the study aimed at skills and knowledge at which loans were managed. The study revealed that many livelihoods that were sustained due to innovativeness and management of credits were SMEs owners and operators. This study recommended that, developing induction centers close to credit seekers and more specifically in the rural poor regions would encourage credit seeking and faster developments of SMEs.

In Uganda, Matovu (2006) carried out a study on Poverty alleviation, the study aimed at a case study of Management style of Uganda finance trust in growing women's SMEs. The study revealed that, the more frequent the inhouse training was done to SMEs, the more literacy level increases hence adhering to credit norms, while if the distant apart between the borrower and the MFIs is far away. The study recommended that, both SMEs and credit provider should put in efforts through training and skills of getting the service at a less cost and effective way.

In Nairobi, a study carried by Kelvin (2011) on the role of MFIs on the credit accessibility and growth of SMEs a case of management of SMEs in Gikomba market, the study aimed to find out how ownership affects growth of SMEs. The study revealed that, ownership and literacy level improved SME management. Therefore, paying back the credit was not a challenge due to increased cash-flow. The study recommended that, decentralizing enterprises and diversifying economic activities would foster growth of SMEs to ownership with more responsibilities; it's also reaching out to far people and SMEs who lack skills of competition and credit management would be reached out by credit providers and competing SMEs.

\section{Theoretical Framework}

This study was guided by Microfinance theory of change (Mohammed Yunus 1995), with backup supports and suggestions from other theorist with similar concepts; Social capital and Development theory (Robert Putnam 1993) and theory of Group lending (Besley and Coate (1995)).

\subsection{Microfinance Theory of Change}

This study was guided by Yunus (1995) Microfinance theory of change, it explains concept of changing ones poor life to better through three simple key steps; a poor person goes to a microfinance provider for credit accessibility to start or expand SMEs operations which yields enough net revenue to repay the credit with interest and still have sufficient profit to increase household income enough to raise the SMEs growth.

Credit accessibility is believed to have natural tendency of growth. Rudd (2011) Microfinance theory of change intended to increase profitability of SMEs and promote types of technological innovations that would stimulate growth in their communities Yaron and McDonald (2002).

Morduch (2000) states; credit accessibility is the first step of growth for SMEs. Second; investing the credit money in a viable SMEs creates ownership responsibility, and Third; Managing the business to yield major return on the investment establishes the profit that gives interest to pay-back the loan, hence SMEs growth.

Theory of Group lending as proposed by Besley and Coate (1995), backs Microfinance Theory of change by exploring regulations on marketing strategies of loans borrowed by individuals or group SMEs with members guaranteeing member colleagues of growth to every member of the group. Theory of group lending promotes individual SMEs growth through group of SMEs communal support through SMEs out rich platform thereby creating credit accessibility to the growth of SMEs.

\section{Methodology of the Study}

\subsection{Research Design}

The study applied mixed method approach especially descriptive and inferential research design. According to Cooper and Schindler (2000), descriptive and inferential research focuses on why questions. In answering the 'why' questions, the study was involved in developing causal explanations. Causal explanations argue that phenomenon $Y$ (growth of SMEs) is affected by variable X (government policy) this design was chosen because it applies closely to the research objectives of the study hence practical in testing the research hypothesis. Descriptive and inferential research design also aimed to gain a better understanding about a problem and to seek new insights and to assess phenomena in a new light (Saunders et al 2008). This study utilized both approaches as the research hypothesis calls for real-life contextual understandings that a quantitative model alone cannot capture (Meissner 2010). Social norms, cultural influence, the borrowers' lives and experiences are some measures that give insight into the repayment problems but can only be captured through a quantitative approach.

\subsection{Study Variables}

The study focused at Management Approach as an influence of Credit Accessibility on Small and Medium Enterprises in Kenya: A case of Kisumu County, and therefore the study consisted of the following variables: 


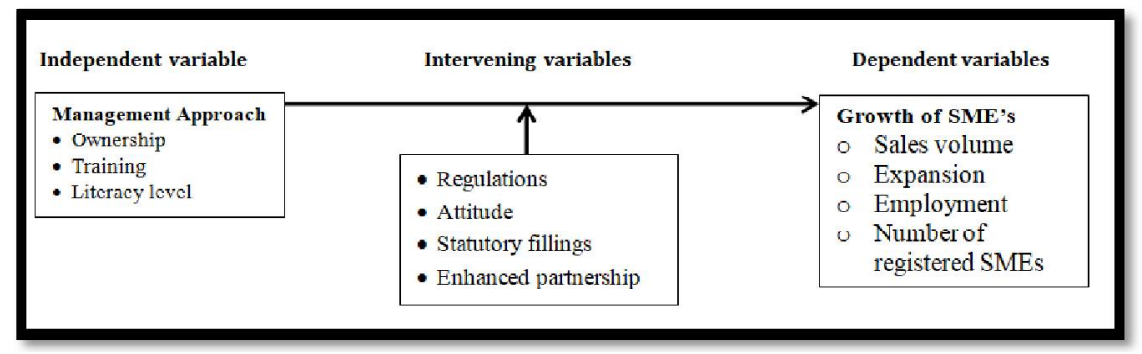

Figure 2

\subsubsection{Dependent Variable}

'growth of small and medium enterprises' included the improved and measurable growth and practice of Sales volume, Expansion, employment and Number of registered, each of which was the end result indicators that directly indicated Management approach through identified variables playing a leading role in influencing the credit accessibility by small and medium enterprises.

\subsubsection{Independent Variables}

Showed Management approach; providing adherence to Microfinance Act 2006 (CAP 493D) and regulations, Ownership, Training and literacy level influences the credits accessibility by small and medium enterprises. All these were measured vide the increasing sales volume, expansion of business in terms acquisition of assets and branches, creation of employment opportunities and increased number of registered Small and Medium Enterprises (SMEs) due to relevant business training improving literacy level and ownership authenticity.

\subsubsection{Intervening Variables}

Could also be recognized through; easy to practice policy regulations, attitude of market players, easy integrated taxation system for filling tax, alongside enhanced public-private partnership in community development agendas made the above independent variables be viably cognizant.

\section{Statistical Tools Used}

Statistical tools used in qualitative data was principles of thematic analysis as stated by Braun and Clarke (2006), it's a method of identifying and analyzing themes within a data set, while quantitative statistical tools were; Percentages, frequency counts, means and tables.

\subsection{Descriptive Statistics Analysis}

Establishment on how MFIs management approaches influence credit accessibility on growth of SMEs was presented in a Likert scale of 5 from the questionnaire for descriptive statistical variables;

Responses were summarized and presented in Table 1, which showed frequency counts and percentages of strongly agree, agree, undecided, disagree and strongly disagree as below;

\begin{tabular}{|c|c|c|c|c|c|c|c|c|c|c|}
\hline \multirow[t]{2}{*}{$\begin{array}{l}\text { Establish how MFIs management } \\
\text { approach influence SMEs growth }\end{array}$} & \multicolumn{2}{|c|}{$\begin{array}{l}\text { Strongly } \\
\text { agree }\end{array}$} & \multicolumn{2}{|c|}{ Agree } & \multicolumn{2}{|c|}{ Undecided } & \multicolumn{2}{|c|}{ Disagree } & \multicolumn{2}{|c|}{$\begin{array}{l}\text { Strongly } \\
\text { disagree }\end{array}$} \\
\hline & Freq. & $\%$ & Freq & $\%$ & Freq. & $\%$ & Freq. & $\%$ & Freq. & $\%$ \\
\hline $\begin{array}{l}\text { Lack of skills on how to manage loans } \\
\text { deter credit accessibility }\end{array}$ & 54 & 31.2 & 47 & 27.2 & 25 & 14.5 & 19 & 10.9 & 28 & 16.2 \\
\hline $\begin{array}{l}\text { There is need to understand MFIs } \\
\text { ownership before seeking credit }\end{array}$ & 49 & 28.3 & 47 & 27.2 & 34 & 19.7 & 24 & 13.9 & 19 & 10.9 \\
\hline $\begin{array}{l}\text { MFIs training induction to SMEs } \\
\text { influences credits accessibility }\end{array}$ & 66 & 38.2 & 47 & 27.2 & 19 & 10.9 & 25 & 14.5 & 16 & 9.2 \\
\hline $\begin{array}{l}\text { The higher the literacy level of SMEs } \\
\text { operators the easy the access to credit }\end{array}$ & 59 & 34.1 & 44 & 25.5 & 28 & 16.2 & 19 & 10.9 & 23 & 13.3 \\
\hline $\begin{array}{l}\text { Culture and traditions of a region } \\
\text { influence credit accessibility }\end{array}$ & 54 & 31.2 & 47 & 27.2 & 25 & 14.5 & 28 & 16.2 & 19 & 10.9 \\
\hline $\begin{array}{l}\text { Attitude of SMEs operators influence } \\
\text { credit accessibility }\end{array}$ & 49 & 28.3 & 24 & 13.9 & 47 & 27.2 & 19 & 10.9 & 34 & 19.7 \\
\hline $\begin{array}{l}\text { Understanding regional economic needs } \\
\text { influences credit accessibility }\end{array}$ & 39 & 22.5 & 35 & 20.2 & 36 & 20.8 & 29 & 16.8 & 34 & 19.7 \\
\hline $\begin{array}{l}\text { Management of MFIs infrastructure } \\
\text { influences credit seeking by SMEs }\end{array}$ & 57 & 32.9 & 45 & 26.0 & 29 & 16.8 & 20 & 11.6 & 22 & 12.7 \\
\hline $\begin{array}{l}\text { Literacy level of SMEs operators } \\
\text { determines the credit accessibility }\end{array}$ & 69 & 39.9 & 49 & 28.3 & 21 & 12.2 & 15 & 8.7 & 19 & 10.9 \\
\hline
\end{tabular}

Table 1: Management Approach

Source: Survey Data (2016) 
Lack of skills on how to manage loans deters credit accessibility was strongly agreed with $31.2 \%$, agreeing $27.2 \%$, undecided $14.5 \%$, disagree $10.9 \%$, strongly disagreed $16.2 \%$; this therefore revealed that, majority of respondents $58.4 \%$ agreed that, management approach of credit accessibility and payback depends on the skills and knowledge of loan management, $27.1 \%$ disagreed, while $14.5 \%$ of respondents were undecided on whether or not lack of skills on how to manage loans deter credit accessibility.

Interview schedule revealed that, majority of informants feel that lack of skills on how to manage loans deters credit accessibility, since most SMEs are financed through family contributions and personal savings. It was further revealed that many SMEs operators were casual employees and not owners of those ventures; hence had little or no knowledge of financing and challenges facing SMEs management. Credit manager from Ahero sub-county commented as below;

CM4ahr: "Reaching out to owners of SMEs in our outreach to management seminars is a challenge because we always meet employees who are engaged on temporarily basis, e.g. when you make a return visit you get different staff."

Annual report by Kikomeo for eight cumulative years between 2008 through to 2015 indicated that, lack of management skills was one of the factors that made members not to seek business credits yet they kept monthly remittance to their voluntary self-help group.

Credit managers primarily serves the interest of investors (MFIs owners) this is what brings management challenge; MFIs owners focus on annual return yield, but none is willing to spend a coin on training of field staff for marketing, or training SMEs operators on better ways to manage their loans.

This finding is in agreement with the study carried out by Nargiza et al (2015) on importance of good management for the growth of SMEs that leads to credit accessibility.

There is need to understand MFIs ownership before seeking credit; strongly agree 28.3\%, agreeing 27.2\%, undecided $19.7 \%$, disagree $13.9 \%$, strongly disagreed $10.9 \%$. This therefore means that, many respondents $55.5 \%$ agreed that knowledge of MFIs ownership before seeking credit was influential, minority of respondents $24.8 \%$ disagree citing that, knowing ownership of MFIs before seeking credit have no influence to credit accessibility, and the only possible influence would be geared towards favoritism. Only 19.7\% were undecided on whether or not knowledge of MFIs ownership before seeking credit had an influence.

Results from the interview schedule revealed that majority of informants feel that having prior knowledge about the MFIs ownership before seeking credit played vital role in credit accessibility and reduction of credit risks. This was on account to evade previous negative experience of MFIs closing down without notice and exposing SMEs savings to high risk of loss. One SMEs operator from Nyakach Sub County commented;

Operator $_{4 n k c:}$ "...My venture is stagnated in growth since one MFIs that recently opened an office here, took off with our savings just when our investment was almost maturing to loans offer...."

It can be deduced that, knowledge of both ownership of MFIs and SMEs is influential in terms of business reliability and sustainability example; The year after post-election violence (2008/2009) was one of the best period MFIs registered many SMEs both as new and continuing ventures after the disastrous loss; but it later turn out to be the period of great loss when many SMEs defaulted on repaying their loans and close-up from operation. They lacked knowledge on how to manage business-recession, besides MFIs management identifying the gap between SMEs operators and the economic.

This study seems to be in agreement with a study carried out by Enyaah (2011) on analysis of the effects of MFIs ownership's influencing credit accessibility, the study establish their relationship with long-term sustainability and possibly prediction towards growth of both MFIs and SMEs.

MFIs training induction to SMEs influences credits accessibility; strongly agree $38.2 \%$, agreeing $27.2 \%$, undecided $10.9 \%$, disagree $14.5 \%$, strongly disagreed $9.2 \%$; this data revealed majority of respondents $65.4 \%$ agreeing that MFIs training induction to SMEs operators would positively influence credit accessibility, this was viewed to improve management of loans by SMEs, while a minority of $23.7 \%$ disagreed citing that, any SMEs seeking credit is already aware and have the knowledge of running their venture, meanwhile $10.9 \%$ were undecided on whether or not training induction to SMEs influenced any credit accessibility.

Interview schedule however, revealed that, majority of informants feel that, MFIs training induction to SMEs play a significant role in credit accessibility, citing reasons driving SMEs to seek credit were varied depending on individual SMEs need and by MFIs training inductions, the urge to access credit would be encouraged. Meanwhile, some informants felt that, MFIs training induction to SMEs wouldn't influence credit accessibility much since the decision to seek credit is solely driven by the owners of SMEs whose need and desire is to grow and expand. One Credit manager from Muhoroni said;

CM $M_{4 m n n}:$ "We train groups of many SME operators thrice annually on our budget but the response to seek credit has been surprisingly low"

According to researcher's findings in the demographic chart (2016), majority of respondents and informants were female, age bracket between 18 to 40, with education level up to secondary, most of whom are employees of SMEs. It can therefore be deduced that, the participants in the training are not the ultimate decision makers in financing the SMEs operations. This was observed as the gap between the training induction and credit accessibility (Appendix H).

This finding was in agreement with Khan and Rahaman (2007) on the impact of microfinance institutions training induction to members seeking credit with a view to promoting small business growth.

The higher the literacy level of SMEs operators, the easy the accessibility to credit; strongly agree $34.1 \%$, agreeing $25.5 \%$, undecided $16.2 \%$, disagree $10.9 \%$, strongly disagreed $13.3 \%$; the above information revealed majority $59.6 \%$ of respondents agree that, higher literacy level of SMEs operators do influence ease of credit accessibility, this is in view to having ability to manage loan within the payback period without illiteracy hitch. $24.2 \%$ of respondents disagree citing that, 
there are already presence of many successful SMEs owners and operators who are illiterate; otherwise $16.2 \%$ of respondents were undecided.

Finding from interview schedule revealed that an average number of informants agree that, higher literacy level of SMEs operators was very influential in credit accessibility, similar breath of informants was observed to dissent the information with one SMEs operator from Ahero town sub-county siting that;

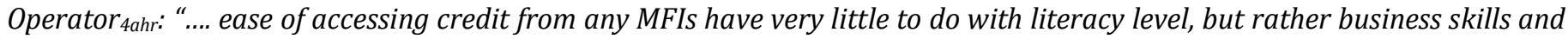
challenges experienced during the actual operations...."

Many MFIs credit managers experienced heard time inducting illiterate SME operators with less than secondary level of education, and similar experience was felt on old SME operators of over 51 years of age, these category of operators had a systemic mindset of doing routine duties every day without a change, and changing their model of operations was impossible, they were disappointed on the employment of unskilled field staff who happens to be family members or relatives of the owners. On the same breath, most of MFIs were also packed with semiskilled staffs who were secondary school leavers without relevant education knowledge, this prompted MFIs management to budget for in-house induction of MFIs field officers before they sent out, this turns out to be very costly, which later is passed on to clients seeking credit in indirect way.

The finding is in agreement with the study carried out by Yeboah (2010) on MFIs training management and development in rural SMEs.

Culture and traditions of a region influence credit accessibility; strongly agree $31.2 \%$, agreeing $27.2 \%$, undecided $14.5 \%$, disagree $16.2 \%$, strongly disagreed $10.9 \%$; this therefore means that, majority of respondents $58.4 \%$ agreed that culture and traditional of a region influence credit accessibility, 27.1\% disagree while $14.5 \%$ of respondents were undecided whether culture and traditional practices of a region played any role or not.

Results from the interview schedule also revealed that majority of informants feel that culture and traditions play very important role in credit accessibility through collaterals in group associations, this helps promote individual economic growth of SMEs by one seeking credit and security spread amongst members of the group. One of SMEs owner in Kisumu West sub county

Operator $_{1 \text { west: " }}$ most of MFIs charges too high interest rate, that's why many SMEs are shy from seeking credits".

Report by Kibuye and Kondele members' organization (Kikomeo-2016) on the model of loan borrowing record annually, indicated that one of the factors that led to low credit accessibility by registered members was the traditions and cultural practices of the residents around different regions. One of the operators from Kibuye market had this to say;

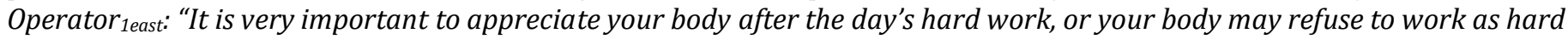
the following day"

It could be deduced therefore, that luxurious life from parts of the operators by way of maintaining some culture and tradition would drain cash mend for business operations and day by day spending would cumulatively reduce the operational running cost of the business, hence closure of the business.

This finding is in agreement with Matovu (2006) on effects of cultural and traditional practices against economic growth of SMEs, with focus to peered lifestyle and negative cultural practices of a growing SMEs operators.

Attitude of SMEs operators influence credit accessibility; strongly agree $28.3 \%$, agreeing $13.9 \%$, undecided $27.2 \%$, disagree $10.9 \%$, strongly disagreed $19.7 \%$; this response therefore confirmed that, majority of respondents $42.2 \%$ agreed with statement citing that, attitude of some SME operators influenced negatively on credit accessibility, similarly respondents of $30.6 \%$ disagreed, while $27.2 \%$ of respondents were undecided on whether attitude of SMEs operators influence credit accessibility.

Interview schedule revealed that many informants relied on the credit history of other operators, some of whom had failed to payback their loans for unexplained purpose and only to blame it later on MFIs. Most attitude of SMEs operators developed from hearsay stories created by SMEs, some from previous disappointed with MFIs credit offers depending on the MFIs management approach to loans. This ideally did not give merited approach to credit accessibility for example; one of the SMEs operators from Kisumu East sub-county said;

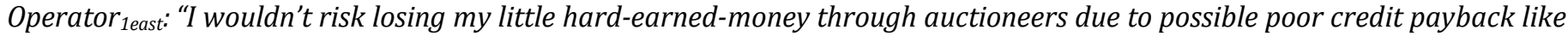
two of my competitors who were frustrated by MFIs."

Another operator from Muhoroni sub-county said;

Operator $_{4 m h n:}$ "These MFIs never listen to SMEs needs, and are always out to maximize their profit by targeting our SMEs savings, that's why they encourage us to seek credit.

Another operator from Kibuye market in Kisumu East sub-county who inherited the family business from the parents said;

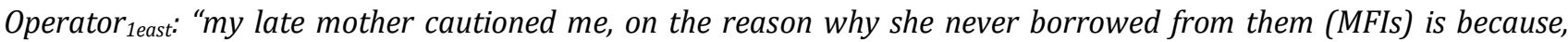
they only lend us blood money that keep suckling our businesses, and that's why our business can't grow"

This finding seems to be in agreement with Kelvin (2011) on the role played by SME operator's attitude towards the growth of SMEs.

MFI's understanding regional economic needs, influences credit accessibility by SMEs; strongly agree $22.5 \%$, agreeing $20.2 \%$, undecided $20.8 \%$, disagree $16.8 \%$, strongly disagreed $19.7 \%$; this revealed that $42.7 \%$ of respondents agreed that if credit managers of MFIs understand regional economic needs, then their MFIs will present credit offers that would influence the local SMEs credit accessibility. Some 36.5\% of respondents disagreed with the statement citing that, whether MFIs understand regional economic needs or not might not contribute to accessibility of credit. Meanwhile $20.8 \%$ of respondents were undecided on whether or not understanding of regional economic needs influenced credit accessibility. 
Interview schedule ironically revealed that many MFI informants instead of understanding the regional economic needs as a guide to package credit offers, majority of MFIs had a pre-costumed standard of language and offer to all their customers like SMEs irrespective of regional economic diversity from different regions. On the flipside, many SMEs informants feel that understanding economic needs of a region influence credit accessibility. The interviews result further confirmed that most SMEs cluster the loan package according to tribal background of owners and associated towns where MFIs headquarter are based. This thematic analysis is generally in agreement with the quantitative analysis. Credit accessibility is measured by growth of SMEs and further proxied by regional economic development which effects credit accessibility.

According to Kisumu County Enterprise Development (KCED-2015), all the 66 microfinance institutions that operates in Kisumu County, are branches whose headquarters are in Nairobi, Thika and Nakuru. This means that, Kisumu County is yet to get home-based MFI with firsthand regional economic touch needs.

This research finding agrees with the study carried out by Oladayo (2014) that the only avenue to be followed by any SMEs for economic empowerment worldwide is to understand the regional economic need before financing.

Management of MFI's infrastructure influences credit seeking by SMEs; strongly agreeing 32.9\%, agree 26.0\%, undecided $16.8 \%$, disagree $11.6 \%$, strongly disagree $12.7 \%$; this therefore means that, majority of respondents $58.9 \%$ agreed with the statement citing that the better outlook of the infrastructure the more SMEs will be influenced in seeking credit. Minority of respondents $24.3 \%$ disagreed with the statement, saying that, there are some MFIs operating from old buildings but with classic credit service to SMEs and the public. $16.8 \%$ of respondents were undecided on whether or not the management of MFIs infrastructure had an influence in credit accessibility.

Interview schedule revealed similar results that, majority of informants feel more comfortable and assured with any MFI whose infrastructure is of classic and modernly built compared to others. It was further observed, that MFIs with glassy office layout enjoyed the prestige of attracting many undecided SMEs owners, as majority of credit seekers judged many MFIs based on the outlook of their infrastructures. SMEs operator from Kisumu North sub-county commented;

Operator 4 north: "MFIs that are capable of giving huge business loans with ease are seen by the outlook of their buildings, their locations and even their office layout. You even find cold drinking water at the reception."

According to KIHBS (2011), the poor management of MFIs infrastructure within the county did influence SMEs credit accessibility negatively, thereby making the county to lag behind in economic growth as was compared with the surrounding five counties. (Appendix G)

It may be deduced that, by virtue of human being a social nature, living by what is seen, many MFIs have capitalize on this concept and win lots of unsuspecting SMEs by simply spending a little extra on infrastructure, one fact is that, the cost of this spending becomes the running cost of MFIs which must be spread out to credit users anyway.

This study is in agreement with Yunus (2007), the founder of the Grameen Bank, was the creation of affordable cost in management to support SMEs.

Literacy level of SMEs operators determines credit accessibility; strongly agree 39.9\%, agree $28.3 \%$, undecided $12.2 \%$, disagree $8.7 \%$, strongly disagree $10.9 \%$. This statistic revealed that, majority of respondents $68.2 \%$ agreed that when the literacy level of SMEs operators is high, then the probability of quick decision in seeking business credit shall also be high. Minority of respondents $19.6 \%$ disagreed without commenting; meanwhile $12.2 \%$ of respondents were undecided on whether or not literacy level played any role in credit accessibility.

Interview schedule revealed that, majority of SMEs informants mostly in the urban areas agreed with the statement, otherwise most of SMEs in the rural did not focus on the literacy level rather most of them were guided by the economic condition of any individual to go into any business as long as individual monthly bills would be paid. Researcher observed that SMEs operating under life economic demands faulted more in repaying the loans when compared to literate ones.

Interview schedule revealed that, MFIs informants agree that, both Management approach of MFIs and SMEs have affected the frequency at which loans are taken; the higher the skills and education of MFIs managers and SMEs operators, the higher the credit accessibility. Many informants cited that, most SMEs growth is steered by the reliability and availability of good Management. Majority of SMEs have been listed by credit rating bureau due to bad credit management, the listing has compelled most SMEs to bow out of operations due to lack of financing and capital. It was noted that most of SMEs operators save their cash in Mpesa and other mobile services, due to the handy-mobile functions and convenience. It may be concluded that majority of SMEs rely on management approach of MFIs and good MFIs infrastructure, SMEs with good credit management and repayment done within the stipulated payback period.

These findings seem to concur with the study by Khan and Rahaman (2007) who found out that, success, good governance and growth of SMEs relied on positive Management approach of both SMEs operators and MFIs credit managers.

Annual credit report by Kikomeo (voluntary savings association owned by SMEs from Kibuye and Kondele markets) 


\section{Document Analysis: Kikomeo Summary for Loan Borrowing Record Annually}

\begin{tabular}{|c|c|c|c|c|c|}
\hline Years & $\begin{array}{c}\text { Registered } \\
\text { Members per } \\
\text { year }\end{array}$ & $\begin{array}{l}\text { Cumulative } \\
\text { Members } \\
\text { annually }\end{array}$ & $\begin{array}{c}\text { Non } \\
\text { Loan seekers }\end{array}$ & $\begin{array}{l}\text { SMEs with active } \\
\text { Loans from MFIs }\end{array}$ & $\begin{array}{c}\text { SMEs seeking } \\
\text { loan }(\%)\end{array}$ \\
\hline 2008 & 72 & 72 & 3 & 69 & 31.94 \\
\hline 2009 & 21 & 93 & 29 & 64 & 29.63 \\
\hline 2010 & 15 & 108 & 52 & 57 & 26.39 \\
\hline 2011 & 33 & 141 & 90 & 51 & 23.61 \\
\hline 2012 & 46 & 187 & 142 & 45 & 20.83 \\
\hline 2013 & 16 & 203 & 171 & 32 & 14.81 \\
\hline 2014 & 00 & 203 & 172 & 31 & 14.35 \\
\hline 2015 & 13 & 216 & 188 & 28 & 12.96 \\
\hline Total & 216 & \multicolumn{3}{|c|}{ Mean $\%$ of credit seeking $174.52 / 8$ years } & 21.82 \\
\hline
\end{tabular}

Above document analysis revealed 8 years since inception between years 2008 to 2015, registered members had risen to 216 while SMEs operators who actively applied for loans in the final year were 28 only. This was as a result of emerging easy and self-regulated mobile loans with easy payback plan at affordable rate.

Above findings revealed that, SMEs growth was perceived on a twin approach depending on the operators' and MFIs locations and mode of operations, that is; town SME operators were exposed to more formal credit accessible opportunities than rural operators. Many MFIs within the same town attracting business competition that prompts a competitive rates, reaching out to SMEs within the same town and offering business supports like; inducting operators on the benefits of savings and seeking credits, and training on how to manage loans amongst many other call-to-treat business approach to get more clients. Findings were in agreement with the study by Mimouni (2012) on self-financing for socioeconomic empowerments that were observed to be the drive behind SMEs growth.

\subsection{Testing Hypotheses}

Based on the objectives of this study, the hypotheses of the study were tested at $5 \%$ level of significance, and a multiple linear regression model was used to investigate these hypotheses; as follows;

- $\mathrm{H}_{\mathrm{o} 1}$ : There is no significant relationship between the influences of Management Approach and growth of

\subsection{SMEs in Kisumu County}

In this study, Management approach was proxied by ownership, training and literacy level, which had a significant and negative effect on job creation, self-proprietorship, management skills and tact, with increased number of SMEs assets. The finding of this study is that ownership under Management approach has a significant and negative effect on SMEs growth through self-proprietorship and job creation.

\subsubsection{GMM System Dynamic Panel-Data Estimation, One Step Results: GSME Series}

\begin{tabular}{|c|c|c|c|c|c|c|}
\hline GSME & Coef. & $\begin{array}{c}\text { Robust } \\
\text { Std. Err. }\end{array}$ & $\mathbf{z}$ & P>I z I & [ 95\% Conf. Interval ] \\
\hline${\mathrm{MA}-\mathrm{O}_{1}}_{\mathrm{MA}-\mathrm{T}_{1}}$ & -.1381292 & .070859 & -.067 & 0.009 & -.1045752 & .2320104 \\
\hline $\mathrm{MA}_{1} \mathrm{~L}_{1}$ & .1565035 & .2053449 & 0.76 & 0.014 & -.2689721 & .1859651 \\
\hline \multicolumn{7}{|c|}{ Table 3 }
\end{tabular}

The regression coefficient is equals -.13813 and is significance at the $5 \%$ level when the dependent variable is measured by GSME. This result implies that for 1 unit increase in Management approach in the operations, the growth index increases assets of SMEs by -.13813 respectively.

Training $\left(\mathrm{T}_{1}\right)$ of both MFIs and SMEs employees have a negative significance at $5 \%$ level with coefficient of .1565035 , when the dependent variable is measured by growth of accessibility to credit, the coefficient of the estimate shows that every one unit increases in credit loss.

Literacy level $\left(\mathrm{L}_{1}\right)$ of both MFIs and SMEs staff was measured by employment of professionals, and the faster mode at which new SMEs are started, this could be explained by observing low dependency ratio, high employment opportunities, improved filing of taxation and improved gross domestic product. 
This result is in concordance with Pasiouras and Kosmidou (2006) who reported that, the management of cost-income ratio influencing the profitability of business venture is determined by the management approach or policy by the owner

\subsubsection{Variables Description (for Above Testing Hypotheses Result)}

\begin{tabular}{|c|c|c|}
\hline Codes & Variables & Proxy \\
\hline${\mathrm{MA}-\mathrm{O}_{1}}$ & Management Approach-ownership & Self-proprietorship, job creation \\
\hline $\mathrm{MA}_{\mathrm{T}} \mathrm{T}_{1}$ & Management Approach-Training & Management skills and tact \\
\hline $\mathrm{MA}_{\mathrm{L}} \mathrm{L}_{1}$ & Management Approach-Literacy level & Employment, increased number of SMEs \\
\hline
\end{tabular}

Sources: Author's Computation (2016)

\subsection{Correlation Matrix}

The correlations between the explanatory variables and the independent variables is depicted as shown in Table 5

\begin{tabular}{|c|c|c|c|c|c|}
\hline & & $\begin{array}{c}\text { Sales } \\
\text { volume }\end{array}$ & Expansion & Employment & $\begin{array}{c}\text { Management } \\
\text { Approach }\end{array}$ \\
\hline Management & Pearson & .085 & .140 & .045 & 1 \\
approach (MA ${ }_{1}$ ) & Correlation Sig. (2- & .274 & .072 & .563 & 253 \\
\hline
\end{tabular}

Table 5: Correlations Matrix of Dependent and Independent Variable $\left(M A_{1}\right)$

Source: Research data (2017)

Note: Correlation is significant at the 0.05 level (2-tailed)

Table above depicts the correlations between the explanatory variables and the dependent variable. It is observed that at $95 \%$ is the level of confidence, since $1 \%$ in Sales volume leads to $0.140 \%$ change in Expansion, $0.045 \%$ change in Employment, and $0.085 \%$ change in Sales volume.

The Sales volume is significantly correlated to Expansion when coefficient $r=0.258$, to Employment when coefficient $r=0.576$, and to Registered SMEs when coefficient $r=0.274$.

The above statistics is positively and significantly correlated to influence the credit accessibility on growth of small and medium enterprises (SMEs).

\section{Summary of Major Findings}

The overall objective of this study was to explore Management approach as an influence to credit accessibility on growth of small and medium enterprises in Kenya, given the pivotal role played by MFIs in supporting the growth of SMEs and that Credit accessibility has been a challenge to SMEs for their growth. The study used a sample of 20 credit managers from MFIs, and 240 SME operators for a 20-year period between 1995 and 2015; the specific study was conducted in six administrative Sub-counties namely; Kisumu East, Kisumu West, Kisumu North, Muhoroni, Nyakach and Nyando subcounties within County Government of Kisumu.

To achieve this objective a Pearson correlation matrix was obtained to determine Management approach as an influence of credit accessibility on growth of SMEs. Management approaches had a significant and negative effect on SMEs growth, the regression coefficient was equals -0.1818 and had a negative significant at the $5 \%$ level when the dependent variable was measured by GSME. This result was in consistence with the empirical evidence of Athanasollou et al. (2008) who observed that the non-performing loans or credit is negatively and significantly related to MFIs profitability.

Management approach has a significant and negative effect on SMEs growth through self-proprietorship and job creation. In table 4.5, the regression coefficient is equals -.13813 and is significance when the dependent variable is measured by GSME. This result is in concordance with Pasiouras and Kosmidou (2006) who reported that, the management of cost-income ratio influencing the profitability of business venture is determined by the management approach or policy by the owner.

\section{Recommendations}

Based on conclusions of the study, it recommends the following:

Stringent approaches of improving credit accessibility and reducing loan faulting's that result in accumulating of loans overdue and penalties for not paying on time and hence non-performance loans and high net charge-offs should be adopted by individual MFIs to keep credit loss provision at low levels. Thus, this study recommends that:

Credit Managers of MFIs should ensure that internal management is in place as appropriate to address sustainable credit accessibility by SMEs. Such management approach as;

- Established authorities and processes approval of loan applications.

- Safeguards provision for SMEs assets management, protection and growth.

- Public display of MFIs information pertaining loaning and other related credit information.

- Appropriate staffing level and training to maintain expertise.

- Regular verification and reconciliation of transaction and accounts.

- Effective use and sound implementation of technology may improve the management approach. 


\section{Suggestion for Further Research}

For future research, this study can be extended to cover longer time periods. Unbalanced panel data can be used to incorporate the microfinance institutions which are recently established with a view to improving SMEs growth. Other econometric techniques can be applied to verify the relationship circumventing credit accessibility. More macroeconomics factors such as real interest rates, exchange rate stock market turnover can be considered as moderating or control factors.

\section{References}

i. Anuja Cabraal (2010) Impact of Microfinance on the Capabilities of Participants in Australia

ii. Athanasoglou, p.p., Brissims, S. N., Aand and Delis, M. D. (2008). Bank specific, industry specific and macroeconomics determinants of MFI determinants of MFIs profitability.

iii. Ayyagari, M., T. Beck, and A. Demirgüç-Kunt, 2007. "Small and Medium Enterprises across the Globe", Small Business Economics 29, 415-434

iv. Besley, T., and S. Coate. 1995. Group Lending, Repayment Incentives and Social Collateral Journal of Development Economics. 46 (1): 1-18.

v. Betty, 2006), In Kenya, Accessibility of microfinance loans have in a larger extent helped the Economic and social development of the rural community

vi. Braun and Clarke (2006) Principles of thematic analysis. Qualitative data analysis CGK (2015) Inter-counties economic performances and index in Kenya

vii. Central Bank of Kenya (CBK-2014), competitive interest rates charged by credit offers.

viii. Charlotte Wagner (June 2013) Growth and Crises on Microfinance in Frankfurt School of Finance \& Management, Frankfurt Germany

ix. Christen, R. P., Rosenberg, R., and Jayadeva, V. (2004). Financial institutions with a double bottom line: Implications for the future of microfinance. Occasional Paper 12. Washington, D.C.: CGAP, July.

x. Cooper and Schindler (2000) explanatory research design and inferential statistics on why questions.

xi. Enyaah, Ransford Charles (2011) Analysis of the effects of Government policy on stock market returns: Empirical evidence of Ghana stock exchange.

xii. Ganka Daniel Nyamsogoro (2010) Financial Sustainability of Rural Microfinance Institutions (MFIs) Tanzania, University of Greenwich

xiii. Hashad Nabil Reen (2014) Repayment determinant for Microfinance Institutions, as per Governing policy on accessing credit.

xiv. Helms, B. (2006). Access for all, Building Inclusive Financial Systems. The World Bank. Washington D.C.

xv. Mbithe Naomi (2010) Accessibility of Microloans on the growth of Small and Medium Enterprises

xvi. Meissner (2010) Real-life contextual understandings of quantitative model.

xvii. Mimouni Karim (2012) financial access and socioeconomic empowerments; drive behind seeking credits.

xviii. Microfinance Act (2006), Chapter 493d, for Licensing, Governance, Supervision, protection of deposits and miscellaneous provisions.

xix. Mohammad Yunus (1995) Group based induction on saving and credit for sustainability: Grameen bank in Bangladesh.

$x x$. Paper presented at the inter-country workshop on the group-based savings and credit for the rural poor sponsored by the international labour organization UN inter-agency panel on people's participation,

xxi. Morduch Jonathan (2000) Accessibility of credits; MFIs as economic step of moving away from poverty

xxii. Okibo Bachanga Walter and Njage Makanga (2014) Effect of economic empowerment on credit borrowed by SMEs, a case of Pamoja Women Development Program (PAWDEP) located in Kiambu Sub-county

xxiii. Oladayo Nathaniel Awojobi (April 2014) Empowering Women through Microfinance, Nigeria,

xxiv. Republic of Kenya. 1989. 1992/94, Small Enterprises and Jua Kali Development in Kenya. Nairobi: Government Printer.

xxv. Rudd Allison (2011) "Microfinance as a poverty alleviant" and quotes; Microfinance theory of Change

xxvi. Sachs J. (2005), The end of poverty: Economic possibilities for our time, Penguin Books, N.Y

xxvii. Saunder, Lewis and Thornhills (2008) the acceptability and appropriateness of research study affected by broader social norms of behavior

xxviii. Yaron and McDonald (2002) Factor affecting accessibility of microfinance services and market players; varied interest rate charged in communities

xxix. Yunus, M. 1995. Testimony before the House [of Representatives of the U.S.] Committee on International. Relations, Fed. News Service, June 27. 